\title{
PUBLIC HEALTH AND AIR POLLUTION IN THE CONTEXT OF SUSTAINABLE URBAN DEVELOPMENT
}

\section{Iryna Ustinova ${ }^{1 \otimes}$ (ㅇ, Grygoryi Trakhtengerz ${ }^{2}$ (])}

${ }^{1}$ Kyiv National University of Construction and Architecture, Kyiv, Ukraine ${ }^{2}$ O.M. Marzeyev Institute of Public Health, National Academy of Medical Sciences of Ukraine, Kyiv, Ukraine

$\triangle$ ustinova.ii@knuba.edu.ua

ABSTRACT - The results of the study of the impact of polluted air on the health of the population in the zone of influence of industrial enterprises of oil refining, as well as urban planning factors and natural and climatic conditions that lead to the strengthening of this impact within the limits of the environmental laws of development are presented.

KEYWORDS - public health, air pollution, urban planning factors, natural and climatic conditions, environmental laws of development, sustainable urban development.

The outcome document of the Rio+20 Conference, in the context of sustainable development of cities and human settlements, notes the importance of supporting adequate air quality as air pollution has a negative impact on human health [1]. According to the World Health Organization (WHO), air pollution represents a significant environmental risk to public health. Globally, this risk accounts for 7 million premature deaths annually and more than 0.5 million in the WHO European Region [2]. Due to increased risk of respiratory and cardiovascular diseases, as well as lung cancer, the negative impact of air pollution reduces life expectancy in the WHO European Region by an average of 1 year [3]. The costs associated with disability due to air pollution in 2010 in the WHO European Region were about $\$ 1.6$ trillion; and the annual economic loss of 2015 due to morbidity and premature mortality caused by air pollution in 44 of the 48 countries of the WHO European Region was estimated to be equivalent to $1 \%$ of their gross domestic product [4]. Subsequently, the WHO resolution Health and Environment: Addressing the Effects of Air Pollution on Health recognized the right to clean air as a fundamental human right [5].

Industry, transport and energy make the greatest contribution to air pollution. In EU countries, fuel combustion was the main source of benzopyrene and some heavy metals emissions in 2015 [6]. At present
$55 \%$ of the world population lives in cities that are directly connected with the development of industry, energy and transport, and by the middle of the XXI century this indicator will reach 68\% [7]. Therefore, among the effective measures to reduce the negative impact of polluted air on public health the UN and WHO materials note the measures in the field of urban development $[4,6,8]$.

In 2016, the age-standardized mortality rate attributed to indoor and outdoor air pollution (per 100,000 population) is almost 35 in the WHO European Region, 15 in Germany, 50 in the Russian Federation and 70 in Ukraine [6]. Thus, the problem of clean air, public health and sustainable urban development is also relevant for Ukraine, where about $70 \%$ of the population is urban.

Purpose of the study

The purpose of the study was to identify the impact of polluted air on the health of the population in the zone of influence of the northern industrial hub of the city of Kremenchuk (Kremenchuk agglomeration ranks $18^{\text {th }}$ out of 23 agglomerations in Ukraine), as well as the factors and conditions that contribute to the strengthening of this impact.

\section{MATERIALS AND METHODS}

The objects of the study were air and soil pollution (which accumulates this pollution) in the zone of influence of the northern industrial hub of the city of Kremenchuk and the health condition of residents of the Molodizhnyi district with which the industrial hub borders. In addition, the natural and climatic conditions (seasonal and regional features of the natural and climatic potential of the atmosphere dispersion) and urban planning factors (the mutual location of the industrial hub and residential development) were considered, the joint action of which contributes to the accumulation of pollution in the air.

The choice of these territories is motivated by the fact that since 2016 the number of complaints received from residents of the Molodizhnyi district to the Kremenchuk City Council regarding air pollution by enterprises of the northern industrial hub, in particular, the unpleasant smell of petroleum products and deteriorating health has increased significantly. In order to determine the composition and concentrations of air pollutants and the main sources of their emissions, 
in 2017 the specialists of the State Institution Marzeev Institute of Public Health of the National Academy of Medical Sciences of Ukraine in the zone of influence of the northern industrial hub of Kremenchuk (in particular, 4 of its powerful enterprises: Oil Refinery Ukrtatnafta, Kremenchuk Plant of Technical Carbon; Kahamlyk Washing and Steaming Station (WSS) and Kremenchuk Thermal Power Plant (TPP)) studied the state of air and soil pollution. The concomitant consideration of natural climatic and urban planning factors is motivated by the fact that the majority of complaints fall on the period of summer - from the end of May to September.

The work uses a systematic approach, methods of population survey, comparative, field and statistical analysis. The content of heavy metal (HM) compounds and benzopyrene in soil and atmospheric air was determined by instrumental and atomic absorption spectral analysis method. The determination of polycyclic aromatic hydrocarbons ( $\mathrm{PAHs}$ ) in air samples was based on low-temperature spectral luminescence analysis; the determination of PAHs in soil samples was carried out by gas chromatographic method; the concentration of the sum of saturated hydrocarbons $\mathrm{C}_{12}-\mathrm{C}_{19}$ and the mass concentration of petrol - by chromatographic method.

Starting position

The technologies of Kremenchuk TPP use natural gas and fuel oil; Kremenchuk Plant of Technical Carbon - coke-chemical and oil raw materials; Ukrtatnafta Oil Refinery specializes in oil processing; Kahamlyk WSS provides preparation of tank cars for oil products loading. The closest residential development to the north industrial hub is in the Molodizhnyi district. Sampling of atmospheric air in the area of the industrial hub was carried out in February, May, August and September 2017. The analysis of population morbidity was made on the basis of the data received from the Health Department of the Kremenchuk City Council Executive Committee.

\section{RESULTS AND DISCUSSION}

In February, the measured concentrations of PAHs and HMs in the atmospheric air of the Molodizhnyi district did not exceed the established maximum permissible concentrations (MPC). On the other hand, snow samples on the territory of the industrial zone revealed the presence of some PAHs and vanadium $\left(0.175 \mathrm{mg} / \mathrm{dm}^{3}\right)$, which indicates the presence of these substances in the atmospheric air as well.

In May, August and September on the territory of the industrial hub and residential development sampling of atmospheric air and soil showed excess content of pollutants, in particular: benzopyrene, benzanthracene, vanadium, cadmium, gasoline and saturated hydrocarbons $\mathrm{C}_{12}-\mathrm{C}_{19}$ (Tables 1,2,3).

On the impact of air pollution on public bealth and self-assessment. The analysis of prevalence of diseases of the adult population of Kremenchuk in the period from 2012 to 2016 established the growth of indicators of the population morbidity with allergic rhinitis in 1.1 times, chronic bronchitis in 1.3 times, bronchial asthma in 1.3 times. Bronchial asthma was $1.3 \%$ higher than the regional rate and obstructive lung diseases was $4.7 \%$ higher. The analysis of the levels of adult population primary morbidity, compared to 2012 , found a gradual increase in allergic rhinitis by 1.3 times and chronic bronchitis by 12 times; excess of the average region indicator for allergic rhinitis by $3.3 \%$, chronic bronchitis by $6.1 \%$, bronchial asthma by $0.7 \%$, obstructive lung diseases by $6.3 \%$. Between 2012 and 2015, there was also a 3-fold increase in the incidence of chronic bronchitis and an 11-fold increase in allergic rhinitis among children.

Taking into account the fact that the city population is not sufficiently covered by preventive medical examinations and does not always seek medical help before clinical manifestations of a disease, the self-assessment of health and attitudes to the factors that form it were investigated (according to the questionnaire survey of the population). Analysis of the survey data made it possible to establish common features inherent to all age groups: the overwhelming majority of respondents, regardless of gender, are concerned about the environmental situation in the city (Fig. 1A). As for concerns about the environmental situation, it was found that the greatest degree of eco-anxiety is typical for the residents of the Molodizhnyi district (Fig. 1A, B). The majority of respondents of all age groups noted the presence of discomfort from industrial facilities functioning in the city, and the main reason for discomfort was the presence of a constant unpleasant smell (Fig. 2).

The survey revealed the features of subjective assessment of the health status of respondents of different ages and sex (Fig. 3, 4).

Almost half of young people (under 35 years of age) are characterized by good assessment of their own health ( $43 \%$ of men and $54 \%$ of women). In persons with existing chronic pathology, allergic diseases and diseases of the respiratory system prevailed in the disease structure. One in six male and one in two female respondents, who have no chronic diseases, have noticed deterioration of health status in the recent period and complained about fatigue and drowsiness - 20\%, headache $-22 \%$, breathing heaviness $-16 \%$.

Respondents of middle age (from 36 to 46 years) were characterized by satisfactory assessment 
Table 1. Content of pollutants in the air and soil in the impact zone of the northern industrial hub of Kremenchuk in May 2017

\begin{tabular}{|c|c|c|c|}
\hline Distance from emission source, (m) & Substance & Concentration & MPC \\
\hline \multicolumn{4}{|c|}{ In the atmospheric air of } \\
\hline \multicolumn{4}{|l|}{ industrial area } \\
\hline \multirow{2}{*}{380} & benzopyrene & 0.51 & $0.1 \mu \mathrm{g}$ per $100 \mathrm{~m}^{3}$ \\
\hline & vanadium & 0.007 & $0.002 \mathrm{mg} / \mathrm{m}^{3}$ \\
\hline \multicolumn{4}{|l|}{ residential development } \\
\hline \multirow{2}{*}{1500} & benzopyrene & 0.53 & $0.1 \mu \mathrm{g}$ per $100 \mathrm{~m}^{3}$ \\
\hline & vanadium & 0.004 & $0.002 \mathrm{mg} / \mathrm{m}^{3}$ \\
\hline \multirow{2}{*}{2170} & benzopyrene & 0.45 & $0.1 \mu \mathrm{g}$ per $100 \mathrm{~m}^{3}$ \\
\hline & vanadium & 0.003 & $0.002 \mathrm{mg} / \mathrm{m}^{3}$ \\
\hline \multirow{2}{*}{2800} & benzopyrene & 0.43 & $0.1 \mu \mathrm{g}$ per $100 \mathrm{~m}^{3}$ \\
\hline & vanadium & 0.002 & $0.002 \mathrm{mg} / \mathrm{m}^{3}$ \\
\hline \multicolumn{4}{|c|}{ In the soil of residential development } \\
\hline Distance from emission source, $(\mathrm{m})$ & Substance & Concentration & MPC of benzopyreney in soil, ( $\mathrm{mg} / \mathrm{kg})$ \\
\hline 380 & benzopyrene & 0.049 & $0.02 \mathrm{mg} / \mathrm{kg}$ \\
\hline 2160 & benzopyrene & 0.036 & $0.02 \mathrm{mg} / \mathrm{kg}$ \\
\hline
\end{tabular}

Table 2. Content of pollutants in the air and soil in the impact zone of the northern industrial hub of Kremenchuk in August 2017

\begin{tabular}{|c|c|c|c|}
\hline Distance from emission source, $(\mathrm{m})$ & Substance & Concentration & MPC \\
\hline \multicolumn{4}{|c|}{ In the atmospheric air (August, $16^{\text {th }}$ ) of } \\
\hline \multicolumn{4}{|l|}{ residential development } \\
\hline \multirow{2}{*}{1400} & benzopyrene & 0.52 & $0.1 \mu \mathrm{g}$ per $100 \mathrm{~m}^{3}$ \\
\hline & benzanthracene* & 0.015 & $0.005 \mathrm{mg} / \mathrm{m}^{3}$ for working area (!) \\
\hline \multicolumn{4}{|c|}{ In the atmospheric air (August, $29-30^{\text {th }}$ ) of } \\
\hline \multicolumn{4}{|l|}{ industrial area } \\
\hline \multirow{2}{*}{500} & benzopyrene & 0.31 & $0.1 \mu \mathrm{g}$ per $100 \mathrm{~m}^{3}$ \\
\hline & benzanthracene* & 0.023 & $0.005 \mathrm{mg} / \mathrm{m}^{3}$ for working area (!) \\
\hline \multicolumn{4}{|l|}{ residential development } \\
\hline 3000 & benzopyrene & 0.35 & $0.1 \mu \mathrm{g}$ per $100 \mathrm{~m}^{3}$ \\
\hline 2300 & benzopyrene & 0.45 & $0.1 \mu \mathrm{g}$ per $100 \mathrm{~m}^{3}$ \\
\hline \multicolumn{4}{|c|}{ In the soil of industrial area (August, $29-30^{\text {th }}$ ) } \\
\hline \multirow{2}{*}{ near Kahamlyk WSS } & vanadium & 193,9 & $150 \mathrm{mg} / \mathrm{dm}^{3}$ \\
\hline & cadmium & 2.44 & $1.5 \mathrm{mg} / \mathrm{dm}^{3}$ \\
\hline
\end{tabular}

Note: the benzanthracene concentration, which is contained in coal tars, which are raw materials of the Plant of Technical Carbon, significantly exceeds the MPC of this substance for the working area (!), while the sampling took place outside the sanitary protection zone (SPZ) of the enterprises of this industrial hub, which is $1000 \mathrm{~m}$.

Table 3. Content of pollutants in the air in the impact zone of the northern industrial hub of Kremenchuk in September 2017

\begin{tabular}{|c|c|c|c|}
\hline Distance from emission source, (m) & Substance & Concentration & MPC \\
\hline \multicolumn{4}{|l|}{ industrial area } \\
\hline \multirow{2}{*}{ near Oil Refinery } & petrol & 28 & $5 \mathrm{mg} / \mathrm{m}^{3}$ \\
\hline & saturated hydrocarbons (12-C19 & 30 & $1 \mathrm{mg} / \mathrm{m}^{3}$ \\
\hline \multirow{2}{*}{$\begin{array}{l}1100 \\
\text { (beyond the SPZ of Oil Refinery) }\end{array}$} & petrol & 8 & $5 \mathrm{mg} / \mathrm{m}^{3}$ \\
\hline & saturated hydrocarbons C12-C19 & 25 & $1 \mathrm{mg} / \mathrm{m}^{3}$ \\
\hline
\end{tabular}


A.

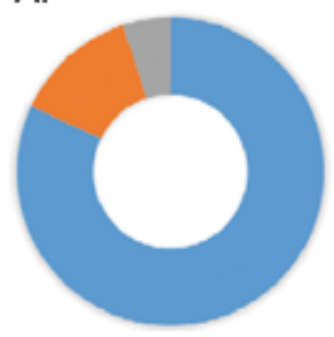

B.

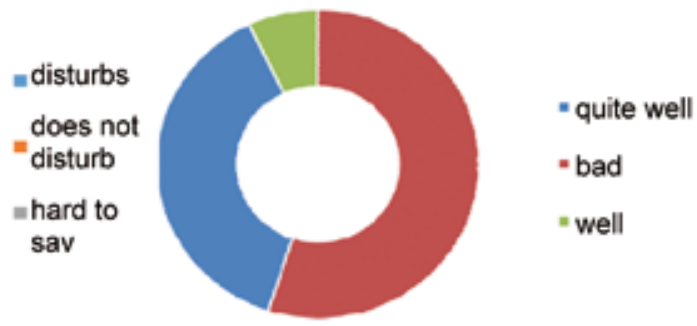

C.

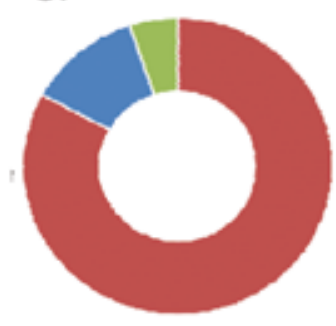

Fig. 1. Population assessment of environmental situation (A) and comparative assessment of environmental wellbeing of Kremenchuk (B) and the Molodizhnyi district (C)
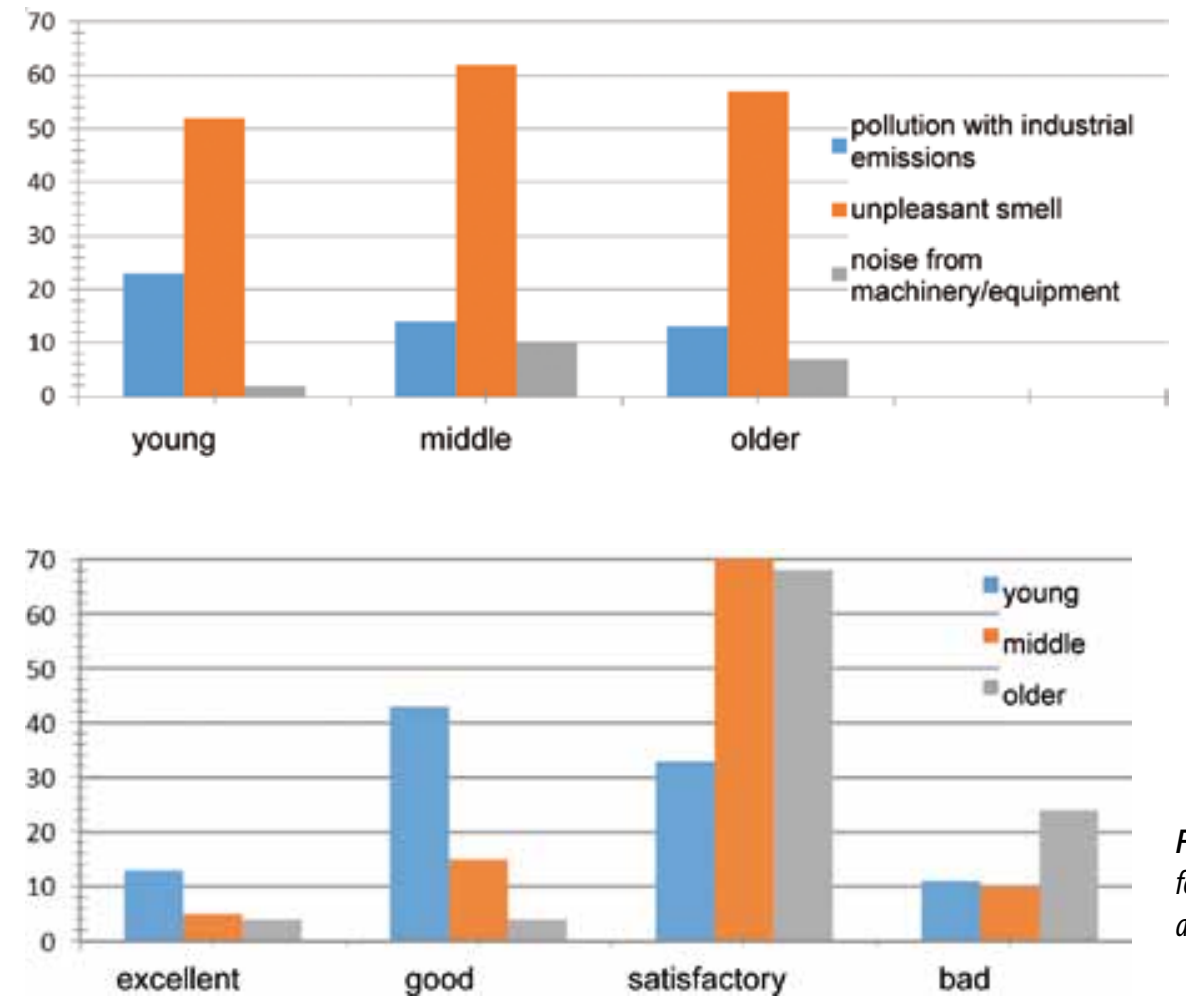

Fig. 2. Main reasons for discomfort as indicated by the population of three age categories (\%)

Fig. 3. Distribution of respondents of different ages (male) by subjective health assessment, (\%)

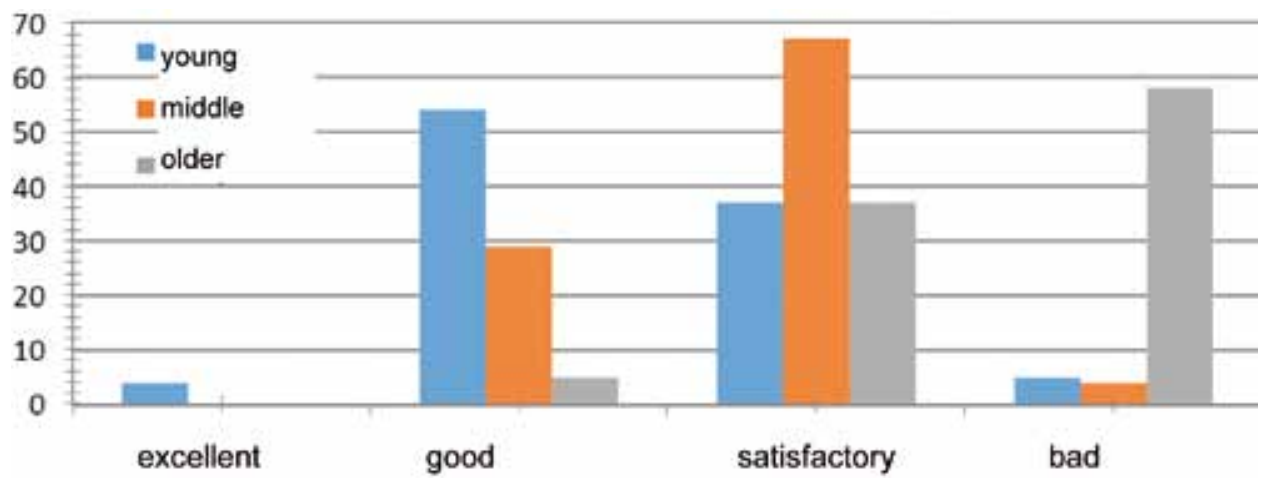

Fig. 4. Distribution of respondents of different ages (female) by subjective health assessment, (\%) 
of their own health, the presence of chronic diseases in most men and a third of women, and deteriorating health regardless of gender. Only $16 \%$ of men and $8 \%$ of women indicated the presence of occupational diseases. Complaints of fatigue and drowsiness - 25\% and breathing heaviness - 19\% (regardless of gender) were typical.

The older age group (over 47 years) was characterized by satisfactory assessment of the health status of men and mainly bad assessment of women; growth of the proportion of people with chronic pathology (diseases of the respiratory and digestive organs, circulatory system and musculoskeletal system); deterioration of health. The typical complaints of respondents in this age group were breathing heaviness (22\%), fatigue and drowsiness $(21 \%)$ and joint pain $(21 \%)$ (regardless of gender).

On the impact of meteorological conditions on air pollution status. Naturally, air pollution depends on industrial emissions (see Tables 1-3). However, meteorological conditions also contribute to the accumulation (transport, dispersion and washing out of the atmosphere) of pollutants. During 1971-2010 in some regions of Ukraine deterioration of favorable conditions for dispersion of harmful impurities in the air has been revealed. This manifestation of climate change has led to significant changes in meteorological conditions in the country since the mid-1990s, which affect the ability of the atmosphere to purify itself [9]. It is established that Kremenchuk is located in natural and climatic conditions, the combined effect of which contributes to accumulating in the air industrial emissions harmful to public health. Firstly, the city is located in an area with a high potential for air pollution (determined by the recurrence of surface temperature inversion, the presence of days with precipitation and wind speeds $<1 \mathrm{~m} / \mathrm{s}$ ); secondly, in a region with a limited climatic potential for self-cleaning of the atmosphere (determined by the presence of days with precipitation and wind speed $s \geq 6 \mathrm{~m} / \mathrm{s}$ ); thirdly, in a region with seasonal features of atmospheric selfcleaning (in July the conditions of pollutants' removal are characterized as limitedly favorable; in AugustOctober - as unfavorable [9]).

On the impact of urban planning factors. The distance from the territory of the surveyed enterprises to the development of the Molodizhnyi district is: Oil Refinery Ukrtatnafta - 2000 m; Kremenchuk Plant of Technical Carbon - 2000 m; Kremenchuk TPP - $2400 \mathrm{~m}$; Kahamlyk WSS - $700 \mathrm{~m}$. According to the cl. 5.5 of State sanitary rules for planning and development of settlements, the specified distances not only correspond to requirements of sizes of a sanitary-protective zone, established for this promuzla
$(1000 \mathrm{~m})$, but also in 2 and more times exceed them (for Kahamlyk WSS - in 14 times, its SPZ - 50 m) [10]. However, natural studies have identified cases where concentrations of harmful impurities in the atmospheric air and soil at the outer boundary of the SPZ facing residential buildings and far beyond were significantly above the maximum permissible concentrations (see Tables 1-3). That is for the enterprises of the northern industrial hub of Kremenchuk normative sizes of sanitary protection zones can be considered as insufficient.

For the Molodizhnyi district, taking into account average annual and seasonal (summer, winter) rose of winds in Kremenchuk [11], the current design standards are practically complied with — regarding the location of residential areas from the windward side for winds prevailing towards industrial enterprises (hubs) with technological processes that are sources of air pollution, harmful, and have an unpleasant odor of chemicals (cl. 5.3, 5.4); the requirements for landscaping sanitary protection zone (cl. 5.13) are also complied with [10]. However, despite this, the inhabitants negatively assess the living conditions in the neighborhood and attribute this assessment to the negative impact of industrial facilities (see Fig. 1).

On the impact of environmental laws of development. By the fact that norms do not work, one can see the effect of a number of environmental laws [12] and, above all, the law of ecosystem self-regulation. According to this law, the rejection of pollution created by humans from biosphere cycles is a manifestation of environmental resistance; strengthening of the negative feedback mechanism and an ultimatum of the environment, a manifestation of which are changes in the gas composition of the atmosphere and climate [13]. The aggregate effect of these factors is aimed at reducing anthropogenic pressure on the natural environment in order to maintain ecological equilibrium through depopulation. The species which is growing numerically, including the species homo sapiens, worsens its environment, which, in turn, does not have time to recover and becomes less suitable for normal life of the species (see Fig. 1-4). In an ecologically balanced system, all byproducts of one species are eliminated by others; if the balance is disturbed, pollution accumulates (see Tables 1-3).

\section{CONCLUSIONS}

1. Air pollution, as a form of environmental degradation, is an indicator of an imbalanced ecosystem. Air pollution is caused by the accumulation of harmful substances in the atmosphere as a result of anthropogenic activities and climate change. It currently acts as an ultimatum feedback 
factor in the population $\leftrightarrow$ environment system, which tends to increase the rate of air pollution.

2. Due to climate change, some regions of Ukraine have experienced significant changes in meteorological conditions since mid-1990s, affecting the atmosphere's self-cleaning ability. This increases the negative impact of polluted air on human health. Deterioration of natural conditions of atmospheric dispersion of pollutants in the region, especially in July-October, is felt by the population of Kremenchuk and causes numerous complaints of people, the climax falls exactly on the summer period (for Kyiv the climax falls on September-October).

3. Approaches to placing the industrial enterprises and rationing of the sizes of their sanitary-protective zones, the majority of which has been drawn up till the middle $90^{\text {th }}$ years of the XX century, need revision. At designing of inhabited objects it is necessary to consider presence of tendencies to growth of negative influence of industrial clusters on adjoining territories.

\section{REFERENCES}

1. Resolution adopted by the General Assembly on 27 July $201266 / 288$. The future we want (http:// www.un.org/ga/search/view_doc. asp?symbol=A/ $\mathrm{RES} / 66 / 288 \&$ Lang=R).

2. Burden of disease from the joint effects of household and ambient air pollution for 2016. Geneva: World Health Organization; 2018 (http://www.who.int/ airpollution/data/AP_joint_effect_BoD_results_ May2018.pdf?ua=1, accessed 17 July 2018).

3. Data and statistics. In: Air quality [website]. Copenhagen: WHO Regional Office for Europe; 2018 (http:// www.euro.who.int/en/ health-topics/environmentand-health/air-quality/data-and-statistics, accessed 17 July 2018).

4. Economic cost of the health impact of air pollution in Europe: clean air, health and wealth. Copenhagen: WHO Regional Office for Europe; 2015 (http://www.euro.who.int/_data/assets/ pdf_file/0004/276772/Economic-cost-health-impactair-pollution-en. pdf, accessed 17 July 2018).

5. Air Quality and Health. Fact sheets on sustainable development goals: health-related challenges. WHO Regional Office for Europe; 2018. (http://www.euro. who.int/_data/assets/pdf_file/0004/385960/fs-sdg3-9-air-rus.pdf?ua=1) (in Russian).

6. Air quality in Europe: 2017 report. Luxembourg: European Environment Agency; 2017 (https://www.eea. europa.eu/publications/air-quality-in-europe-2017, accessed 17 July 2018).

7. UN News, May 16th, 2018, New York. Department of Economic and Social Affairs (https://www.un.org/ development/desa/ru/news/population/2018-worldurbanization-prospects.html) (in Russian).
8. System of global indicators for sustainable development goals and targets of the 2030 Agenda for Sustainable Development. New York: United Nations Organization; 2018 (https://unstats.un.org/sdgs/ indicators/Global\%20Indicator\%20Framework\%20 after\%20refinement_Rus.pdf) (in Russian).

9. Malytska L.V., Balabukh V.O., 2013. Change in the self-cleaning ability of the atmosphere as a manifestation of climate change (https://www.researchgate. net/publication/326319294_ZMINA_ZDATNOSTI_ATMOSFERI_DO_SAMOOCIS̄ENNA_AK_ PROAOA_ZMINI_KLIMATU) (in Ukrainian).

10. State sanitary rules for planning and development of settlements No. 173-96. - M.: Ukrarhstroyinform, 2001. - 108 p. https://zakon.rada.gov.ua/laws/show/ z0379-96

11. Materials of the master plan of Kremenchuk, Poltava region. The main drawing (fragment). Scheme of planning restrictions (https://www.kremen.gov.ua/ assets/ uploads/files/._generalnyj_plan.jpg) (in Ukrainian).

12. Ustinova I., Trakhtengerts G., 2019. Health risks associated with waste accumulation in the context of environmental laws of development. Archiv euromedica 2019, vol.9, №1, 15-17 (https://doi. org/10.35630/2199-885X/2019/9/1/15)

13. DolNYK, V.R., 1992. Whether there are biological mechanisms of regulation of the number of people, Nature: № 6, p. 3-16 (in Russian). 